\title{
Soldier Load Carriage, Injuries, Rehabilitation and Physical Conditioning: An International Approach
}

\author{
Robin Orr ${ }^{1, *(\mathbb{D})}$, Rodney Pope ${ }^{1,2}\left(\mathbb{D}\right.$, Thiago Jambo Alves Lopes ${ }^{3,4}$, Dieter Leyk ${ }^{5,6}$, Sam Blacker ${ }^{7}$, \\ Beatriz Sanz Bustillo-Aguirre ${ }^{8,9}$ and Joseph J. Knapik ${ }^{1,10}$ \\ 1 Tactical Research Unit, Bond University, Gold Coast 4213, Australia; rpope@csu.edu.au (R.P.); \\ joseph.j.knapik.civ@mail.mil (J.J.K.) \\ 2 School of Community Health, Charles Sturt University, Albury 2640, Australia \\ 3 Research Laboratory of Exercise Science, Centro de Educação Física Almirante Adalberto Nunes, \\ Brazilian Navy, Rio de Janeiro 21941-901, Brazil; ThiagoJambo@hotmail.com \\ 4 Post-Graduation Program in Operational Human Performance/PPGDHO, Brazilian Air Force, University of \\ the Air Force, Rio de Janeiro 21941-901, Brazil \\ 5 Research Group Epidemiology of Performance, German Sport University Cologne, 50933 Cologne, Germany; \\ dieterleyk@bundeswehr.org \\ 6 Bundeswehr Institute for Preventive Medicine, 56626 Andernach, Germany \\ 7 Occupational Performance Research Group, Institute of Sport, University of Chichester, \\ West Sussex PO19 6PE, UK; S.Blacker@chi.ac.uk \\ 8 Ministry of Defence, Paseo de la Castellana 109, 28046 Madrid, Spain; beabustillo@telefonica.net \\ 9 Universidad San Pablo-CEU, CEU Universities, Avenida Montepríncipe s/n, Bohadilla del Monte, \\ 28668 Madrid, Spain \\ 10 United States Army Research Institute of Environmental Medicine, Natick, MA 01760, USA \\ check for \\ updates \\ * Correspondence: rorr@bond.edu.au; Tel.: +61-5595-5530
}

Citation: Orr, R.; Pope, R.; Lopes, T.J.A.; Leyk, D.; Blacker, S.; Bustillo-Aguirre, B.S.; Knapik, J.J. Soldier Load Carriage, Injuries, Rehabilitation and Physical Conditioning: An International Approach. Int. J. Environ. Res. Public Health 2021, 18, 4010. https:// doi.org/10.3390/ijerph18084010

Academic Editor: Paul Tchounwou

Received: 1 March 2021

Accepted: 7 April 2021

Published: 11 April 2021

Publisher's Note: MDPI stays neutral with regard to jurisdictional claims in published maps and institutional affiliations.

Copyright: (c) 2021 by the authors. Licensee MDPI, Basel, Switzerland. This article is an open access article distributed under the terms and conditions of the Creative Commons Attribution (CC BY) license (https:// creativecommons.org/licenses/by/ $4.0 /)$.

\begin{abstract}
Soldiers are often required to carry heavy loads that can exceed $45 \mathrm{~kg}$. The physiological costs and biomechanical responses to these loads, whilst varying with the contexts in which they are carried, have led to soldier injuries. These injuries can range from musculoskeletal injuries (e.g., joint/ligamentous injuries and stress fractures) to neurological injuries (e.g., paresthesias), and impact on both the soldier and the army in which they serve. Following treatment to facilitate initial recovery from injuries, soldiers must be progressively reconditioned for load carriage. Optimal conditioning and reconditioning practices include load carriage sessions with a frequency of one session every 10-14 days in conjunction with a program of both resistance and aerobic training. Speed of march and grade and type of terrain covered are factors that can be adjusted to manipulate load carriage intensity, limiting the need to adjust load weight alone. Factors external to the load carriage program, such as other military duties, can also impart physical loading and must be considered as part of any load carriage conditioning/reconditioning program.
\end{abstract}

Keywords: military; exposure; occupational injury; pack march; reconditioning; return to work; injury risk management

\section{Introduction}

From the deserts in Africa [1] and Iraq [2] to the jungles of Vietnam [3]; from the marshes of the Falklands [4] to the urban sprawl of Somalia [5]; and from traversing the flat lands of rice paddies in Vietnam [6] and poppy fields in Afghanistan [7] to the hilly Kokoda Track of Papua New Guinea [8], Toktong pass of Korea [9] and Shah-i-Kot Valley of Afghanistan [10], soldiers have been required to fight battles for survival while wearing and carrying heavy occupational loads. These loads are composed of equipment and stores designed to ensure protection (e.g., body armour), lethality (e.g., weapon systems and ammunition), and sustainment (e.g., food and water) and are worn on the head (e.g., ballistic helmet), torso (e.g., body armour, load bearing vests, chest rigs, patrol pack), thigh 
(e.g., side arm or stores in thigh pockets) and feet (e.g., boots) as well as being carried in the hands (e.g., primary weapon systems). Whilst these items are important for soldier survival, the loads also impart risks due to factors which include fatigue and the increased energy cost associated with prolonged load carriage [11,12]. The loads carried by the soldier may reduce their physiological capability, mobility, attention to task, marksmanship and grenade throw ability [13-19]. Furthermore, load carriage tasks have been associated with soldier injuries and a history of load carriage injuries increases the risk of future load carriage injuries [20,21]. Hence, preventing load carriage injuries and optimising the physical rehabilitation of injured soldiers to reduce future injury risks and enhance physical, cognitive and technical performance is of importance.

The purpose of this article is to review the physiological and biomechanical responses to load carriage and how these relate to injuries, injury prevention, and rehabilitation after injury.

\section{The Weight of the Soldier's Load}

It must be acknowledged that the requirement to carry load is not unique to soldiers. Law enforcement personnel are required to carry daily occupational loads that can range from approximately $10 \mathrm{~kg}$ for a general duties officer [22] up to approximately 20-25 kg [23,24] and even $40 \mathrm{~kg}$ [25] for a specialist tactical response officer. Likewise, firefighters are often required to generally carry loads of over $20 \mathrm{~kg}$ while wearing firefighting personal protective clothing [26]. Nevertheless, although these loads are notable, they are typically lighter than those carried by soldiers as soldiers are often in situations where they do not have the relatively close support networks that are commonly available to other tactical groups such as law enforcement and firefighting personnel. As such, soldiers must carry more equipment and stores. While the soldier's load may vary depending on their Corps (e.g., infantry, armoured, and artillery [27]), roles within a given unit (e.g., rifleman, grenadier, and section commander [28]) and tasks (e.g., patrolling on foot or in a vehicle, and sentry duty [27]), the loads carried by US [21,28-30], Australian [27], British [31], Spanish [18], and German [32-34] soldiers can weigh from approximately $25 \mathrm{~kg}$ to well over $45 \mathrm{~kg}$. Of most concern, research suggests that regardless of advances in weaponry, changes in theatres of war, and changes to technology in general, the loads carried by soldiers into combat are increasing $[15,35]$. Not only may the weight of these loads differ between occupations but the contexts in which these loads are carried may vary, law enforcement officers may wear their relatively lighter loads daily for the duration of their career, while firefighters will don their loads for specific periods (e.g., while fighting a structural fire) and military personnel, again depending on their unit's roles and tasks, could carry loads for varying lengths of time and over varying distances $[36,37]$.

\section{Physiological Responses to Load Carriage}

The weight of the loads carried by soldiers is known to elicit a physiological cost. Increases in load weight have been found to reduce endurance time [38] and increase the energy cost of walking (forwards and backwards, and up and down stairs), and running [39-41]. However, it is not only the weight of the load being carried that influences the soldier's physiological responses to a load carriage task, so too do the contexts in which loads are carried [15]. An example of a contextual influence is the speed at which the carrier is moving while the load is carried, whereby increases in speed of movement increase the energy cost of carrying a given load to the point where it has been suggested that increases in speed may have a greater impact on energy expenditure than increases in load weight [42].

Changes in both terrain gradients and terrain surfaces have also been observed to affect the energy costs of load carriage, such that increases in gradients traversed increase the energy costs of carrying loads [43-45]. As with speed, increases in the grade (angle) of the terrain may impart a greater energy cost to the soldier than increases in load weight [45]. When considering the incline of terrain, Crowder et al. [45] advised that the grade might 
be more important than the load from an energy cost perspective because a $1 \%$ increase in grade increased energy cost by approximately 10-fold more than a $1 \%$ increase in load with no change in grade. Changes in energy cost per unit of downhill gradient are not linear but rather assume a " $U$ " shape. That is, as the downhill grade increases, energy cost initially decreases, reaches a minimum and then increases again. Lloyd and Cooke [46] observed that as gradients declined from zero to $-5 \%$, there was a minor reduction in oxygen consumption, with consumption then increasing steadily as the gradient decreased from -12 to $-27 \%$. Further, Santee et al. [47], investigating the impact of declining gradients of up to $-12 \%$ (during 20 min of treadmill walking carrying 9.1 and $18.1 \mathrm{~kg}$ backpacks), reported similar reductions in energy requirements occurring with declines in grade to $-12 \%$, when compared to level walking. Considering these findings regarding the impacts of incline and decline terrain gradients on load carriage energy expenditure, it is noteworthy that studies assessing energy costs on both inclining (up to $+27 \%$ ) and declining gradients (down to $-30 \%$ ) have reported that load carriage on inclining gradients is more energy costly than that on decline gradients [46-48]. The nature of the terrain to be traversed should also be considered, as different surfaces incur different physiological costs. Energy cost when carrying load increases across the following list of terrain types: sealed roads, dirt roads, light bush, heavy bush, swamp, loose sand, and deep (10-20 cm) snow [49,50].

As such, not only must the weight being carried by the soldier be considered but so too must the context in which the load is carried, with speed of march and grade and type of terrain also requiring consideration. These contextual factors may provide a means for increasing the load carriage training intensity for a soldier recovering from injury without increasing their carried weight, and so may be of value in a load carriage reconditioning program.

\section{Biomechanical Responses to Load Carriage}

In addition to the physiological costs, load carriage tasks alter biomechanics, including changes to the soldier's posture, gait kinematics (stride length, stride frequency, etc.), and ground reaction forces when walking $[15,51]$. Alterations to forward trunk lean, spine shape, spinal compression, spinal shearing forces, and thoraco-pelvic rhythm have all been associated with carrying loads [52-55]. Load carriage increases postural sway [56-60] and the amount of force generated in the medial-lateral axis [61]. Likewise, load carriage has been associated with changes in the parameters of gait, including changes in the duration of the double support phase, stride length and stride frequency, with these changes dependent on the load and the sex of the carrier [51,55,62-67]. Finally, ground reaction forces increase in downward, antero-posterior, and medio-lateral directions as the carried load weight increases [61-63,67-70].

\section{Injuries Associated with Soldier Load Carriage}

When the aforementioned physiological and biomechanical factors are considered in combination, the potential for soldier load carriage to lead to injuries becomes apparent. The physiological cost of carrying the load can lead to fatigue [12]. The increased energy cost and increased and repetitive muscular force requirements can lead to central or generalised fatigue and localised muscle fatigue increasing the risk of injury to the soldier [11]. Changes to spinal loading, gait patterns, and ground impact forces (through increases in the total volume of impact forces over time [61]) can likely increase the risk of musculoskeletal injuries, particularly during prolonged and/or high-intensity load carriage activities [71].

In terms of injury types, load carriage tasks are associated with causing injuries in soldiers that range from fractures to ligamentous damage and from skin blistering to neurological injuries [15,20,21,30,72-76]. Injury body site data from both specific load carriage events $[69,77]$ and longitudinal studies $[20,74]$ suggest that the lower limbs are a leading site of injury from load carriage, with the knee, ankle and foot found to be common sites of musculoskeletal injuries $[69,77]$. However, some differences in the distribution of these injury sites between sexes may exist. A study by Orr et al. [78] investigating sex 
differences in soldier load carriage injuries found that female soldiers were more than twice as likely as their male counterparts to suffer from a foot injury, whilst in male soldiers, the ankle was the leading lower-limb injury site and accounted for a larger proportion of injuries. All other injury anatomical locations were similar for men and women, in the proportions of injuries they hosted.

In aggregated injury data representing all injuries in an army population accrued over an extended period of time, the back is typically, although not always [73], the second most common site of load carriage injuries after the lower limbs [20,69]. However, in a study of a single load carriage event, the back was the leading site of injuries that led to a soldier's inability to complete the march [69]. This finding is supported by a retrospective cohort study by Orr et al. [78], which found that, when injuries were separated into body sites (e.g., knee, ankle, and foot), the lower back presented as the leading site of injuries in both male and female soldiers [78]. Again, a sex-specific difference was found, in which female soldiers, while suffering similar proportions of lower back injuries, suffered more severe lower back injuries than male soldiers [78]. When an individual walks with a backpack load, forward lean is increased, generating cyclic stresses on the vertebrae, intervertebral discs, muscles, and other spinal structures with each step [21]. Further, heavy loads do not move in synchrony with the trunk and trunk stiffness increases with such heavy loads due to both active co-contraction of the abdominal and paraspinal muscles and paraspinal reflexes. The combined stresses on vertebra, discs, muscles and other spinal structures are likely associated with back pain and injuries experienced in susceptible individuals [21].

Stress fractures (fatigue fractures) appear to be due to a bone remodeling imbalance, where the physiological processes that remove bone tissue outpace processes that produce new bone in stressed areas; stress fractures are typically associated with repetitive bone loading in activities such as walking with loads and other repetitive actions for which individuals are not adequately conditioned $[79,80]$. In military populations, common sites of stress fractures include the pelvis, tibia, calcaneus, and metatarsals [81,82]. Acknowledging that factors other than load carriage (e.g., running volume [30]) contribute to stress fractures, load carriage itself has been found to be a cause of stress fractures. In fact, the first report of stress fractures in the literature was by Dr Breithaupt, who noted the condition in Prussian Army soldiers returning from long marches, although he likely misconstrued the aetiology [83]. The injury was later termed "march fracture" since it was often seen in soldiers involved in marching with loads [83,84]. In a study of pelvic stress fractures in female soldiers, Pope et al. [81] identified the longer step length requirement typical of female soldiers (to keep 'in-step' with male soldiers, who are on average taller, during pack marches) as contributing to specific pubic ramus stress fractures in the female soldiers.

Neurological injuries are also associated with load carriage tasks and include several paresthesias (brachial plexus, digitalgia and meralgia) $[75,76]$. With a mechanism of injury that can involve either neural traction or compression, causes of paresthesias include loads transferred through backpack shoulder straps (brachial plexus palsy [76]), poorly fitting boots (digitalgia paresthetica [76]) or wearing body armour that compresses the thighs while seated for long periods of time (meralgia paresthetica [75]). Although the incidence rates for these injuries are not high compared to those for other load carriage injuries [75,76], recovery can take up to several months [85], with surgical intervention for brachial plexus palsy recommended if there is failure to recover strength and endurance after 24 months [86].

\section{The Wider Impacts of Soldier Load Carriage Injuries}

The impacts of injuries to soldiers while carrying loads can be traced through history. Circa 400 BC, following the long marches of Cyrus' infamous 10,000 Greek mercenaries, the army was thought to have suffered from stress fractures, torn ligaments, muscle damage, blisters and abrasions [87]. In 1870, the Prussian Guards fighting in the FrancoPrussian War left the Rhine with 30,000 soldiers but lost 12,000 fighting soldiers from fatigue induced by carrying heavy loads over the weeks of marching [88]. In 1944, during 
World War II, American troops were said to have been so overloaded that their loads were attributed with causing deaths in the water during landings at Omaha Beach [89]. In 1983, US soldiers assaulting an airhead in Grenada were so overloaded that a large number of them were left on the roadside on intravenous drips and unable to continue to fight [89]. More recently, research suggested that nearly a half (45\%) of US combat forces reported suffering a musculoskeletal injury during a 12-month deployment and the authors concluded that tasks requiring physical energy expenditure such as load carriage, lifting, or standing resulted in an increased risk of musculoskeletal injury in this study; lifting/carrying, dismounted patrols, and physical training were associated with $26 \%$ of the reported musculoskeletal injuries [90].

Thus, the potential impact of load carriage injuries on an army can be devastating, adversely affecting its combat capability [91]. Noting the impacts of injuries on army capability, injury prevention, including prevention of recurrences through rehabilitation, is considered by some as a force multiplier [92], a term acknowledging that reducing injuries and optimising rehabilitation will substantially increase combat capability. This makes sense intuitively. For example, if a soldier is injured and they cannot go out on a foot patrol, the rest of the unit must then perform the task with fewer personnel, who may now have to carry additional mission essential stores (increasing their load) with a reduced lethality capability (one less soldier to engage the enemy), factors that both increase the risk of injury and death to the remaining soldiers.

Noting these impacts of load carriage injuries on strategic capability, preventing injuries is of critical importance. This assertion is strengthened by the fact that previous injury is a risk factor for future injury [20,93-95]. A study by Orr et al. [20] found that, of soldiers injured while carrying load during basic training, 32\% sustained an additional injury (to the same or another body site) within the first 12 months of service in an operational unit and overall $52 \%$ of those injured reported sustaining an additional load carriage injury (to the same or another body site) at some time during their career. Not only is the prevention of load carriage injuries paramount, but so too is the optimisation of an injured soldier's rehabilitation for return to work (especially after a load carriage injury), as their ability to return affects not only the individual soldier but also the fighting capability of their unit.

\section{Physical Conditioning and Rehabilitation for Soldier Load Carriage Tasks}

Soldiers will often be the physical platform upon which heavy loads are carried [96], especially in austere or isolated environments where alternative methods are not readily available. In attempting to reduce injury risk in load carriage contexts, the hierarchy of controls for hazards should be considered. This hierarchy includes elimination, substitution, isolation, engineering controls, administrative controls, and personal protective equipment [96]. Elimination, substitution, isolation, and significant engineering controls are rarely considered viable options for control of injury risks arising from load carriage in military training and operational settings, due to requirements such as stealth, movement (affecting proximity of stores), and self-sufficiency during operational duties. The soldier must therefore be physically robust enough to withstand the forces imparted by the loads they must carry [96]. Recognition of the need for soldiers to be physically conditioned and robust enough to carry load is not new and can be traced back to Flavius Renatus who, in his epitome Epitoma rei militaris, described the physical training of Roman soldiers to carry loads and march long distances [97]. Following injury from any cause, soldiers must therefore be supported to recover, return to work and be reconditioned for load carriage.

Immediately following injury, emphasis will necessarily be on early detection, stabilisation, diagnosis and treatment of the injuries, to prevent further harm [98]. These topics are beyond the scope of this article and clinical guidance in these areas is available from many other sources, dependent on the specific type of injury. However, for optimal outcomes, immediately following injury stabilisation the focus must turn to: preventing unnecessary loss of physical conditioning; returning the soldier to work as soon as possible 
using approaches that will support their recovery from injury and build their confidence in their capacity to return to work; and facilitating the progressive physical reconditioning of the soldier for load carriage and other military tasks $[99,100]$.

Deconditioning, loss of confidence, loss of function and isolation from the work team can occur rapidly when the usual activity levels and work participation of soldiers reduce following injury, during the initial treatment phase [101]. It is therefore essential that physical conditioning and progressive return to work commence as soon as the injury is stabilised and concurrently with injury treatment, within the bounds of what is safe and beneficial for the soldier [102,103]. For example, a soldier who has experienced a tibial stress fracture may be prohibited from full weight bearing for some time to unload the bone and allow healing, but assuming the stress fracture is stable and they are not required to wear a plaster cast, they may be able to participate in 'water running' in deep water (eliminating weight bearing through the injured leg) during this time, in order to maintain aerobic fitness levels, muscle function and joint movement [101]. They may also be able to participate in strength training, seated or in other positions that do not require weight bearing through the injured leg. In addition, they may be able to undertake a range of usual military tasks, which do not require full weight bearing through the injured leg, in familiar work environments and supported by peers and supervisors. The aim is always to maintain as much conditioning and normal functioning and interaction in the work environment as possible, while at the same time protecting the healing process for the injury $[99,100,104]$.

Once the initial tissue healing phase is complete and the soldier is ready to return to, and progressively rebuild their capacity, for weight-bearing activities consideration should be given to preparation and reconditioning for load carriage and other military tasks. As with most forms of conditioning and return to work rehabilitation, specificity is of importance and concepts such as the 'principle of specificity' [105] and 'Specific Adaptation to Imposed Demands' [105] should form part of preparing and reconditioning soldiers for load carriage and other military tasks. Research shows that load carriagespecific training is optimal to improve load carriage performance [106-108]. Furthermore, Rudzki [109] compared groups of military recruits assigned to either a running platoon or a load marching platoon, and the load marching group were subjectively rated by staff as performing better at military tasks overall than the run group.

Given that load carriage itself constitutes a source of injury risk, the frequency with which load carriage training is scheduled during preparation or reconditioning following injury is of importance. Research suggests that a load carriage-specific session should be conducted at least once every seven to 14 days $[106,107]$. However, with an increased risk of injury and no additional improvements in load carriage performance found when sessions were greater than four per month [110], the recommendation is that load carriage-specific sessions are conducted no more than once every 10 to 14 days, since a further increase in frequency will typically not increase performance but may increase the risk of injury [30]. This reasoning is also strengthened by the observation of a slow recovery of neuromuscular function in the trunk and limbs up to $48-72 \mathrm{~h}$ after a load carriage bout $[11,111,112])$. For example, in a study by Leyk et al. [112], military ambulance workers performed a maximal stretcher transport with a mean load of $25 \mathrm{~kg}$ on each side and wearing $10 \mathrm{~kg}$ of standard military clothing. Following this task, grip strength was still significantly reduced $72 \mathrm{~h}$ later, leading the authors to assume that the vertical movements of the stretcher led to eccentric stress and to muscle damage during the maximal stretcher transport.

As part of a load carriage conditioning program, intensity and volume need to progressively increase, at a safe rate, to meet the occupational requirements of the soldier. Considering this, while volume can be manipulated by changing the duration or distance of a load carriage event, intensity can be more adequately controlled by manipulating the speed of march, grade, and type of terrain. Exploiting these factors may be particularly useful in the early stages of reconditioning following injury, when loads carried, speeds of movement, or forces applied to specific body parts need to be limited. For example, if 
the rehabilitation focus was on increasing weight bearing through the recovering body site of injury but current aerobic fitness was limited, load mass could be increased from 15 to $20 \mathrm{~kg}$, while the speed of march could be decreased $(5.0 \mathrm{~km} / \mathrm{h}$ to $4.5 \mathrm{~km} / \mathrm{h})$. This example demonstrates how, while relative energy costs and workloads can be kept similar, gradual increases to actual load mass can be made. Alternatively, if the rehabilitation focus was to increase load carriage-specific aerobic fitness but no additional load mass was to be added to the recovering body site, the load mass could be kept constant (e.g., $15 \mathrm{~kg}$ ), while the surface grade could be increased (0 to 3\%) or the terrain swapped from formed roadway to soft sand, thereby maintaining load mass but increasing energy costs and workload to facilitate physical conditioning while avoiding overload of specific body sites.

While load carriage-specific sessions, limited to every 10 to 14 days, are an essential component of load carriage conditioning and reconditioning programs, so too are resistance and aerobic training [106,107]. A combination of resistance and aerobic training has been associated with improvements in load carriage performance [106-108]. Studies show that upper body relative strength (strength per unit of body mass) is more highly correlated to loaded road march performance than lower body relative strength $[108,113]$. Furthermore, increases in aerobic and musculoskeletal fitness are likely essential to prevent future injury, with lower levels of these measures associated with an increased risk of injury in soldiers [114-116]. As such, resistance training (notably relative strength based) and aerobic conditioning should form part of the load carriage conditioning/reconditioning plan for soldiers required to carry loads [107].

Factors external to the load carriage program need to be considered. If the soldier is to remain with their unit whilst undergoing conditioning or reconditioning for load carriage, the impacts of their other duties need to be considered and where necessary reduced to aid in prevention of injury or reinjury [117]. Program-Induced Cumulative Overload (PICO) is a term used to highlight the impacts that other duties and tasks of a physical nature can have on a soldier undertaking a physical conditioning program [118]. As an example, soldiers may be required to complete basic weapon skill training wearing full loads or spend a period of time marching on a parade ground prior to a load carriage conditioning session [118]. These additional musculoskeletal loads may pre-fatigue the soldier, possibly increasing their risk of injury during any subsequent planned load carriage session. Other examples include informal distances covered by soldiers simply moving between lessons, the mess, the barracks, etc., with these distances often equating to 7-11 km per day in some situations $[119,120]$ and further increasing the total training load. On this basis, daily program factors other than load carriage training need to be considered if the load carriage conditioning or reconditioning plan is to be suitably progressive without leading to excessive overload. To mitigate some of these concerns, consideration of the program could allow for load carriage conditioning to be completed as part of other programmed activities. For example, loads worn during a $40 \mathrm{~min}$ weapon training session could constitute the load carriage conditioning session for a particular 10-14 days period, with progression achieved by including marching to and/or from the weapon training session with loads. Likewise, portions of the soldier's day, once every 10-14 days, could involve wearing load while undertaking programmed military training or administration, thereby providing a loading benefit when the soldiers move around their military area during the day.

While this paper has focussed on the physical aspects of load carriage, a final consideration is the impact of mental acuity associated with load carriage. The psychological impacts of physical injury on return to work and performance, and impacts of an injury on mental health are beyond the scope of this paper. However, it should be noted that load carriage is known to impact on aspects of mental acuity, such as attention to task [13]. As such, adding cognitive challenges to the rehabilitation of personnel while conducting load carriage tasks (e.g., remembering number sequences, and identifying the number of 'red circles' or 'blue squares' on a marching route) could be beneficial. Likewise, the addition of military psychologists to the allied health team may usefully inform the overall rehabilitation process. 


\section{Conclusions}

With soldiers required to carry increasingly heavy external loads that have potential to cause injury, optimal conditioning and reconditioning (following injury) practices are of importance to both the individual and the army in which they serve. When implemented, load carriage conditioning should include an appropriate load carriage-specific session every 10-14 days, with training progressions achieved through manipulation of load weight, speed, distance, and grade and type of terrain. The load carriage conditioning program should also include aerobic fitness and resistance training sessions, while considering factors external to the load carriage program which can impart a physical load, such as other military duties and training (particularly those including load carriage).

Author Contributions: R.O., R.P., T.J.A.L., D.L., S.B., B.S.B.-A., and J.J.K. Conceptualization, R.O., R.P., and J.J.K.; resources, R.O., and R.P.; writing-original draft preparation, R.O., R.P., T.J.A.L., D.L., S.B., B.S.B.-A., and J.J.K.; writing—review and editing, R.O., R.P., T.J.A.L., D.L., S.B., B.S.B.-A., and J.J.K.; project administration, R.O. All authors have read and agreed to the published version of the manuscript.

Funding: This research received no external funding.

Institutional Review Board Statement: No institutional review was required given that this work was a literature of already published research.

Informed Consent Statement: Not applicable.

Data Availability Statement: Not applicable.

Conflicts of Interest: The authors declare no conflict of interest.

\section{References}

1. Johnston, M. At the Front Line: Experiences of Australian Soldiers in World War 2; Cambridge University Press: Cambridge, UK, 1996.

2. Porter, S. The Soldier's Load. Infantry 1992, May-June, 19-22.

3. Mckay, G. Delta Four: Australian Rifleman in Vietnam; Allen \& Unwin: Crows Nest, Australia, 1996.

4. Hasting, M.; Jenkins, S. The Battle for the Falklands; W W Norton \& Coy: New York, NY, USA, 1983.

5. Solgere, A. A soldier's load ... revisited. Marine Corps Gazette 1999, 83, 35-36.

6. Taylor, J. Last out: 4 R.A.R./N. Z. (ANZAC) Battalion's Second Tour in Vietnam; Allen \& Unwin: Crows Nest, Australia, 2001.

7. Gardner, H. Fighting Afghanistan's Opium Dependency as a Means of Distrupting al Qaeda's Illicit Funding. Ph.D. Thesis, Boston University, Boston, MA, USA, 2006.

8. Brune, P. A Bastard of a Place: The Australians in Papua; Allen \& Unwin: Crows Nest, Australia, 2003.

9. Camp, D. Toktong Ridge runners-1st Battalion, 7th Marines. Leatherneck 2000, 83, 40.

10. Kraft, N. Lessons learned from a light infantry company during Operation Anaconda. Infantry 2002, 91, 28-31.

11. Blacker, S.; Fallowfield, J.; Bilzon, J.; Willems, M. Neuromuscular Function Following Prolonged Load Carriage on Level and Downhill Gradients. Aviat. Space Environ. Med. 2010, 81, 745-753. [CrossRef]

12. Fallowfield, J.; Blacker, S.; Willems, M.; Davey, T.; Layden, J. Neuromuscular and cardiovascular responses of Royal Marine recruits to load carriage in the field. Appl. Ergon. 2012, 43, 1131-1137. [CrossRef]

13. Orr, R.; Pope, R.; Johnston, V.; Coyle, J. Soldier self-reported reductions in task performance associated with operational load carriage. J. Aust. Strength Cond. 2013, 21,39-46.

14. Carlton, S.; Orr, R. The impact of occupational load carriage on carrier mobility: A critical review of the literature. Int. J. Occup. Saf. Ergon. 2014, 20, 33-41. [CrossRef] [PubMed]

15. Knapik, J.; Reynolds, K. Chapter 11: Load carriage in military operations: A review of historical, physiological, biomechanical and medical aspects. In Military Quantitative Physiology: Problems and Concepts in Military Operational Medicine; Borden Institute: Fort Detrick, MD, USA, 2012; pp. 303-337.

16. Treloar, L.; Alison, K.; Billing, D. Effect of load carriage on performance of an explosive, anaerobic military task. Mil. Med. 2011, 176, 1027-1031. [CrossRef] [PubMed]

17. Billing, D.; Silk, A.; Tofari, P.; Hunt, A. Effects of military load carriage on susceptibility to enemy fire during tactical combat movements. J. Strength Cond. Res. 2015, 29, S134-S138. [CrossRef]

18. Gil-Cosano, J.; Orantes-Gonzalez, E.; Heredia-Jimenez, J. Effect of carrying different military equipment during a fatigue test on shooting performance. Eur. J. Sport Sci 2019, 19, 186-191. [CrossRef] [PubMed]

19. Giles, G.E.; Hasselquist, L.; Caruso, C.; Eddy, M.D. Load Carriage and Physical Exertion Influence Cognitive Control in Military Scenarios. Med. Sci. Sports Exerc. 2019, 51, 2540-2546. [CrossRef] [PubMed] 
20. Orr, R.; Coyle, J.; Johnston, V.; Pope, R. Self-reported load carriage injuries of military soldiers. Int. J. Inj. Contr. Saf. Promot. 2017, 24, 189-197. [CrossRef]

21. Knapik, J.; Reynolds, K. Load carriage-related injury mechanisms, risk factors, and prevention. In The Mechanobiology and Mechanophysiology of Military-Related Injuries; Springer: Berlin/Heidelberg, Germany, 2015; pp. 107-137. [CrossRef]

22. Baran, K.; Dulla, J.; Orr, R.; Dawes, J.; Pope, R. Duty loads carried by the LA sheriff's department deputies. J. Aust. Strength Cond. 2018, 26, 34-38.

23. Carlton, S.; Carbone, P.; Stierli, M.; Orr, R. The Impact of Occupational Load Carriage on the Mobility of the Tactical Police Officer. J. Aust. Strength Cond. 2014, 22, 32-37.

24. Blacker, S.; Carter, J.; Wilkinson, D.; Richmond, V.; Rayson, M.; Peattie, M. Physiological responses of Police Officers during job simulations wearing chemical, biological, radiological and nuclear personal protective equipment. Ergonomics 2013, 56, 137-147. [CrossRef] [PubMed]

25. Keeler, J. The Effect of Tactical Tasks and Gear on Muscle Activation of SWAT Officers. Master's Thesis, University of Kentucky, Lexington, Kentucky, 2014.

26. Carlton, A.; Gorey, R.; Orr, R. The Impact of Suppressing a Structural Fire on Firefighter Hydration. J. Aust. Strength Cond. 2016, 24, 27-33.

27. Orr, R.; Pope, R.; Coyle, J.; Johnston, V. Occupational Loads Carried by Australian Soldiers on Military Operations. J. Health Saf. Environ. 2015, 31, 451-467.

28. Dean, C. The Modern Warrior's Combat Load-Dismounted Combat Operations in Afghanistan. In Proceedings of the International Congress on Soldier's Performance, Jyväskylä, Finland, 18 May 2005.

29. Bachkosky, J.; Andrews, M.; Douglass, R.; Feigley, J.; Felton, L.; Fernandez, F.; Fratarangelo, P.; Johnson-Winegar, A.; Kohn, R.; Polmar, N.; et al. Lightening the Load; NRAC 07-02; Naval Research Advisory Committee: Arlington, VA, USA, 2007.

30. Hauschild, V.; Roy, T.; Grier, T.; Schuh, A.; Jones, B. Foot Marching, Load Carriage, and Injury Risk; Technical Information Paper No. 12-054-0616; Army Public Health Center Aberdeen Proving Ground-Edgewood Area United States: Aberdeen Proving Ground, MD, USA, 2016.

31. Brown, N.; Hobson, S.; Kerr, J.; Pengelley, R.; Wasserbly, D.; Williams, H. Battle of the bulge: Getting to grips with the burdens of war. Jane's Int. Def. Rev. 2010, 43, 40.

32. Eßfeld, D.; Rüther, T.; Wunderlich, M.; Sievert, A. Entwicklung Einsatznaher Leistungstests und Prüfverfahren (Abschlussbericht zum Verbundprojekt M/SAB1/3/A011); Forschungsbericht aus der Wehrmedizin: Bonn, Germany, 2007.

33. Rohde, U.; Erley, O.; Rüther, T.; Wunderlich, M.; Leyk, D. Leistungsanforderungen bei typischen soldatischen Einsatzbelastungen. Wehrmed. Mschr. 2007, 51, 138-142.

34. Hackfort, D.; Leyk, D. Psychophysische Leistungsfähigkeit und militärische Fitness vor dem Hintergrund der Einsatzerfordernisse und des Leistungszustandes der Soldatinnen und Soldaten (Abschlussbericht zum Verbundforschungsprojekt M/GSP0/BA014/BA914); Forschungsbericht aus der Wehrmedizin: Bonn, Germany, 2013.

35. Orr, R. The History of the Soldier's Load. Aust. Army J. 2010, VII, 67-88.

36. Orr, R.M.; Dulla, J.; Schram, B.; Canetti, E. Focus on Officer Wellness: Police Officer Load Carriage Requirements. Police Chief 2020, 4, 18-20.

37. Orr, R.M. Load carriage for the tactical operator: Impacts and conditioning-A review. J. Aust. Strength Cond. 2012, $20,23-29$.

38. Koerhuis, C.; Veenstra, B.; van Dijk, J.; Delleman, N. Predicting Marching Capacity While Carrying Extremely Heavy Loads. Mil. Med. 2009, 174, 1300-1307. [CrossRef]

39. Pederson, A.; Stokke, R.; Mamen, A. Effects of extra load position on energy expenditure in treadmill running. Eur. J. Appl. Physiol. 2007, 102, 27-31. [CrossRef] [PubMed]

40. Blacker, S.; Fallowfield, J.; Bilzon, J.; Willems, M. Physiological responses to load carriage during level and downhill treadmill walking. Med. Sport. 2009, 13, 116-124. [CrossRef]

41. Chung, M.; Lee, Y.; Lee, I.; Choi, K. Physiological workload evaluation of carrying soft drink beverage boxes on the back. Appl. Ergon. 2005, 36, 569-574. [CrossRef] [PubMed]

42. Soule, R.; Pandolf, K.; Goldman, R. Energy expenditure of heavy load carriage. Ergonomics 1978, 21, 373-381. [CrossRef]

43. Scott, P.; Ramabhai, L. Load Carrying: In situ Physiological responses of an infantry platoon. Ergonomics 2000, $2000,18-24$.

44. Lyons, J.; Allsopp, A.; Bilzon, J. Influences of body composition upon the relative metabolic and cardiovascular demands of load-carriage. Occup. Med. 2005, 55, 380-384. [CrossRef] [PubMed]

45. Crowder, T.; Beekley, M.; Sturdivant, R.; Johnson, C.; Lumpkin, A. Metabolic effects of soldier performance on a simulated graded road march while wearing two functionally equivalent military ensembles. Mil. Med. 2007, 172, 596-602. [CrossRef] [PubMed]

46. Lloyd, R.; Cooke, C. The oxygen consumption associated with unloaded walking and load carriage using two different backpack designs. Eur. J. Appl. Physiol. 2000, 81, 486-492. [CrossRef]

47. Santee, W.; Allison, W.; Blachard, L.; Small, M. A proposed model for load carriage on sloped terrain. Aviat. Space Environ. Med. 2001, 72, 562-566. [PubMed]

48. Pimental, N.; Pandolf, K. Energy expenditure while standing or walking slowly uphill or downhill with loads. Ergonomics 1979, 22, 963-973. [CrossRef]

49. Soule, R.; Goldman, R. Terrain coefficients for energy cost prediction. J. Appl. Physiol. 1972, 32, 706-708. [CrossRef] [PubMed] 
50. Pandolf, K.; Haisman, M.; Goldman, R. Metabolic energy expenditure and terrain coefficients for walking on snow. Ergonomics 1976, 19, 683-690. [CrossRef] [PubMed]

51. Seay, J. Biomechanics of Load Carriage-Historical Perspectives and Recent Insights. J. Strength Cond. Res. 2015, 29 (Suppl. S11), S129-S133. [CrossRef]

52. Meakin, J.; Smith, F.; Gilbert, F.; Aspden, R. The effect of axial load on the sagittal plane curvature of the upright human spine in vivo. J. Biomech. 2008, 41, 2850-2854. [CrossRef] [PubMed]

53. Fowler, N.; Rodacki, A.; Rodacki, C. Changes in stature and spine kinematics during a loaded walking task. Gait Posture 2006, 23, 133-141. [CrossRef] [PubMed]

54. Attwells, R.; Birrell, S.A.; Hooper, R.H.; Mansfield, N.J. Influence of carrying heavy loads on soldier's posture, movements and gait. Ergonomics 2006, 49, 1527-1537. [CrossRef]

55. Majumdar, D.; Pal, M. Effects of military load carriage on kinematics of gait. Ergonomics 2010, 53, 782-791. [CrossRef] [PubMed]

56. Schiffman, J.; Bensel, C.; Hasselquist, L.; Norton, K.; Piscitelle, L. The Effects of Soldier's Loads on Postural Sway; Military Performance Division, US Army Research Institute of Environmental Medicine: Natick, MA, USA, 2004; pp. 1-8.

57. Zultowski, I.; Aruin, A. Carrying loads and postural sway in standing: The effect of load placement and magnitude. Work 2008, 30, 359-368. [PubMed]

58. Schiffman, J.; Bensel, C.; Hasselquist, L.; Gregorczyk, K.; Piscitelle, L. Effects of carried weight on random motion and traditional measures of postural sway. Appl. Ergon. 2005, 37, 607-614. [CrossRef]

59. Qu, X.; Nussbaum, M. Effects of external loads on balance control during upright stance: Experimental results and model-based predictions. Gait Posture 2009, 29, 23-30. [CrossRef] [PubMed]

60. May, B.; Tomporowski, P.; Ferrara, M. Effects of Backpack Load on Balance and Decisional Processes. Mil. Med. 2009, 174, 1308-1312. [CrossRef]

61. Birrell, S.; Hooper, R.; Haslam, R. The effect of military load carriage on ground reaction forces. Gait Posture 2007, 26, 611-614. [CrossRef] [PubMed]

62. Kinoshita, H. Effects of different loads and carrying systems on selected biomechanical parameters describing walking gait. Ergonomics 1985, 28, 1347-1362. [CrossRef] [PubMed]

63. Lloyd, R.; Cooke, C. Kinetic changes associated with load carriage using two rucksack designs. Ergonomics 2000, 43, 1331-1341. [CrossRef]

64. Harman, E.; Han, K.; Frykman, P. Load-speed interaction effects on the biomechanics of backpack load carriage. In Proceedings of the RTO Meeting Proceedings 56: Soldier Mobility: Innovations in Load Carriage System Design and Evaluation, Kingston, ON, Canada, 27-29 June 2000.

65. Ling, W.; Houston, V.; Tsai, Y.; Chui, K.; Kirk, J. Women's load carriage performance using modular lightweight load-carrying equipment. Mil. Med. 2004, 169, 914-919. [CrossRef] [PubMed]

66. Birrell, S.; Haslam, R. The effect of military load carriage on 3-D lower limb kinematics and spatiotemporal parameters. Ergonomics 2009, 52, 1298-1304. [CrossRef]

67. Polcyn, A.; Bensel, C.; Harman, E.; Obusek, J. The effects of load weight: A summary analysis of maximal performance, physiological and biomechanical results from four studies of load carriage systems. In Proceedings of the RTO Meeting Proceedings 56: Soldier Mobility: Innovations in Load Carriage System Design and Evaluation, Kingston, ON, Canada, 27-29 June 2000.

68. Park, K.; Hur, P.; Rosengren, K.; Horn, G.; Hsiao-Wecksler, E. Changes in Kinetic And Kinematic Gait Parameters Due To Firefighting Air Bottle Configuration. In Proceedings of the North American Congress on Biomechanics (NACOB), Ann Arbor, MI, USA, 5 August 2008.

69. Knapik, J.; Reynolds, K.; Staab, J.; Vogel, J.; Jones, B. Injuries associated with strenuous road marching. Mil. Med. 1992, 157, 64-67. [CrossRef]

70. Birrell, S.; Haslam, R. The influence of rifle carriage on the kinetics of human gait. Ergonomics 2008, 51, 816-826. [CrossRef] [PubMed]

71. Holt, K.; Wagenaar, R.; Kubo, M.; LaFiandra, M.; Obusek, J. Modulation of force transmission to the head while carrying a backpack load at different walking speeds. J. Biomech. 2005, 38, 569-574. [CrossRef]

72. Orr, R.; Pope, R.; Johnston, V.; Coyle, J. Soldier occupational load carriage: A narrative review of associated injuries. Int. J. Inj Contr. Saf. Promot. 2014, 21, 388-396. [CrossRef] [PubMed]

73. Knapik, J. Injuries and Injury Prevention During Foot Marching. J. Spec. Oper. Med. 2013, 14, 131-135.

74. Orr, R.; Johnston, V.; Coyle, J.; Pope, R. Reported load carriage injuries of the Australian army soldier. J. Occup. Rehabil. 2015, 25, 316-322. [CrossRef]

75. Knapik, J.; Reynolds, K.; Orr, R.; Pope, R. Load Carriage-Related Paresthesias (Part 2): Meralgia Paresthetica. J. Spec. Oper. Med. 2017, 17, 94. [PubMed]

76. Knapik, J.; Reynolds, K.; Orr, R.; Pope, R. Load Carriage-Related Paresthesias (Part 1): Rucksack Palsy and Digitalgia Paresthetica. J. Spec. Oper. Med. 2016, 15, 37-42.

77. Reynolds, K.; White, J.; Knapik, J.; Witt, C.; Amoroso, P. Injuries and risk factors in a 100-mile (161-km) infantry road march. Prev. Med. 1999, 28, 167-173. [CrossRef]

78. Orr, R.; Pope, R. Gender differences in load carriage injuries of Australian army soldiers. BMC Musculoskelet. Disord. 2016, 17, 488. [CrossRef] 
79. Nordin, M.; Frankel, V. Basic Biomechanics of the Musculoskeletal System, 3rd ed.; Lippincott, Williams \& Wilkins: Philadelphia, PA, USA, 2001.

80. Knapik, J.; Montain, S.; McGraw, S.; Grier, T.; Ely, M.; Jones, B. Stress fracture risk factors in basic combat training. Int. J. Sports Med. 2012, 33, 940-946. [CrossRef]

81. Pope, R. Prevention of pelvic stress fractures in female army recruits. Mil. Med. 1999, 164, 370-373. [CrossRef]

82. Boden, B.; Osbahr, D. High-risk stress fractures: Evaluation and treatment. J. Am. Acad. Orthop. Surg. 2000, 8, 344-353. [CrossRef]

83. Carlson, G.; Wertz, R. March fracture, including others than those of the foot. Radiology 1944, 43, 48-54. [CrossRef]

84. DeVan, W.; Carlton, D. The march fracture persists: A report on 145 cases during a fifteen-month period at an infantry basic training center. Am. J. Surg. 1954, 87, 227-231. [CrossRef]

85. Makela, J.; Ramstad, R.; Mattila, V.; Pihlajamaki, H. Brachial plexus lesions after backpack carriage in young adults. Clin. Orthop. Relat. Res. 2006, 452, 205-209. [PubMed]

86. Drye, C.; Zachazewski, J. Peripheral Nerve Injuries. In Athletic Injuries and Rehabilitation; Zachazewski, J.E., Magee, D.J., Quillen, W.S., Eds.; W.B. Saunders: Philadelphia, PA, USA, 1996.

87. Lee, J. A Greek Army on the March: Soldiers and Survival in Xenophon's Anabasis; Cambridge University Press: New York, NY, USA, 2007.

88. Lothian, N. The load carried by the soldier. J. R. Army Med. Corps 1921, 38, 9-24, 241-263, 342-351, 448-458.

89. Mayville, W.C. A Soldier's Load. Infantry 1987, Jan/Feb 87, 25-28.

90. Roy, T.; Knapik, J.; Ritland, B.; Murphy, N.; Sharp, M. Risk factors for musculoskeletal injuries for soldiers deployed to Afghanistan. Aviat. Space Environ. Med. 2012, 83, 1060-1066. [CrossRef] [PubMed]

91. Orr, R.; Pope, R.; Johnston, V.; Coyle, J. Load carriage and its force impact. Aust. Def. Force J. J. Aust. Prof. Arms 2011, 185, 52-63.

92. Butler, N. Injury Prevention as a Combat Multiplier; Army War Coll Carlisle Barracks: Carlisle, PA, USA, 2008.

93. Robinson, M.; Siddall, A.; Bilzon, J.; Thompson, D.; Greeves, J.; Izard, R.; Stokes, K. Low fitness, low body mass and prior injury predict injury risk during military recruit training: A prospective cohort study in the British Army. BMJ Open Sport Exerc. Med. 2016, 2, e000100. [CrossRef] [PubMed]

94. Andersen, K.; Grimshaw, P.; Kelso, R.; Bentley, D. Musculoskeletal lower limb injury risk in army populations. Sports Med.-Open 2016, 2, 22. [CrossRef] [PubMed]

95. Schneider, G.; Bigelow, C.; Amoroso, P. Evaluating risk of re-injury among 1214 army airborne soldiers using a stratified survival model. Am. J. Prev. Med. 2000, 18, 156-163. [CrossRef]

96. Orr, R.; Pope, R. Load Carriage: An Integrated Risk Management Approach. J. Strength Cond. Res. 2015, 29 (Suppl. S11), S119-S128. [CrossRef] [PubMed]

97. Renatus, F. Vegetius: Epitome of Military Science, 2nd ed.; Liverpool University Press: Liverpool, UK, 1996.

98. Whitfill, T.; Haggard, R.; Bierner, S.; Pransky, G.; Hassett, R.; Gatchel, R. Early intervention options for acute low back pain patients: A randomized clinical trial with one-year follow-up outcomes. J. Occup. Rehabil. 2010, 20, 256-263. [CrossRef] [PubMed]

99. Porteous, J. Rehabilitation of injured or ill Australian Defence Force (ADF) Members. J. Mil. Veterans Health 2007, 16, 14.

100. Besemann, M. Physical rehabilitation following polytrauma. The Canadian Forces physical Rehabilitation program $2008-2011$. Can. J. Surg. 2011, 54, S135-S141. [CrossRef] [PubMed]

101. Dembe, A. The social consequences of occupational injuries and illnesses. Am. J. Ind. Med. 2001, 40, 403-417. [CrossRef]

102. Steding-Ehrenborg, K.; Hedén, B.; Herbertsson, P.; Arheden, H. A longitudinal study on cardiac effects of deconditioning and physical reconditioning using the anterior cruciate ligament injury as a model. Clin. Physiol. Funct. Imaging 2013, 33, 423-430. [CrossRef] [PubMed]

103. Olivier, N.; Legrand, R.; Rogez, J.; Berthoin, S.; Weissland, T. Effects of knee surgery on cardiac function in soccer players. Am. J. Phys. Med. Rehabil. 2007, 86, 45-49. [CrossRef]

104. Sharma, J.; Greeves, J.; Byers, M.; Bennett, A.; Spears, I. Musculoskeletal injuries in British Army recruits: A prospective study of diagnosis-specific incidence and rehabilitation times. BMC Musculoskelet. Disord. 2015, 16, 106. [CrossRef] [PubMed]

105. Alver, B.; Sell, K.; Deuster, P. NSCA's Essentials of Tactical Strength and Conditioning; Human Kinetics: Champaign, IL, USA, 2017.

106. Orr, R.; Pope, R.; Johnston, V.; Coyle, J. Load carriage: Minimising soldier injuries through physical conditioning-A narrative review. J. Mil. Veterans Health 2010, 18, 31-38.

107. Knapik, J.; Harman, E.; Steelman, R.; Graham, B. A systematic review of the effects of physical training on load carriage performance. J. Strength Cond. Res. 2012, 26, 585-597. [CrossRef]

108. Robinson, J.; Roberts, A.; Irving, S.; Orr, R. Aerobic Fitness is of Greater Importance Than Strength and Power in the Load Carriage Performance of Specialist Police. Int. J. Exerc. Sci. 2018, 11, 987-998.

109. Rudzki, S. Weight-load marching as a method of conditioning Australian Army recruits. Mil. Med. 1989, 154, 201-205. [CrossRef] [PubMed]

110. Knapik, J.; Bahrke, M.; Staab, J.; Reynolds, K.; Vogel, J.; O'Connor, J. Frequency of Loaded Road March Training and Performance on a Loaded Road March. T13-90; Military Performance Division, US Army Research Institute of Environmental Medicine: Natick, MA, USA, 1990; p. 52.

111. Leyk, D.; Rohde, U.; Erley, O.; Gorges, W.; Wunderlich, M.; Ruther, T.; Essfeld, D. Recovery of hand grip strength and hand steadiness after exhausting manual stretcher carriage. Eur. J. Appl. Physiol. 2006, 96, 593-599. [CrossRef] [PubMed] 
112. Leyk, D.; Rohde, U.; Erley, O.; Gorges, W.; Essfeld, D.; Erren, T. Maximal manual stretcher carriage: Performance and recovery of male and female ambulance workers. Ergonomics 2007, 50, 752-762. [CrossRef]

113. Coakley, S.; Myers, S.; Walker, E.; Hale, B.; Jackson, S.; Greeves, J.; Roberts, R.; Blacker, S. 1.5 mile run time and body mass predict 8 mile loaded march performance, irrespective of sex. J. Sci. Med. Sport 2019, 22, 217-221. [CrossRef] [PubMed]

114. Anderson, M.; Grier, T.; Canham-Chervak, M.; Bushman, T.; Jones, B.H. Occupation and other risk factors for injury among enlisted US Army Soldiers. Public Health 2015, 129, 531-538. [CrossRef]

115. Knapik, J. The importance of physical fitness for injury prevention: Part 1. J. Spec. Oper. Med. 2015, 15, 123-127. [PubMed]

116. Sarah, J.; Gribbin, T.; Lisman, P.; Murphy, K.; Deuster, P. Systematic review of the association between physical fitness and musculoskeletal injury risk: Part 2-Muscular endurance and muscular strength. J. Strength Cond. Res. 2017, 31, 3218-3234.

117. Schuh-Renner, A.; Grier, T.; Canham-Chervak, M.; Hauschild, V.; Roy, T.; Fletcher, J.; Jones, B. Risk factors for injury associated with low, moderate, and high mileage road marching in a US Army infantry brigade. J. Sci. Med. Sport 2017, 20, S28-S33. [CrossRef] [PubMed]

118. Orr, R.; Knapik, J.; Pope, R. Avoiding Program-Induced Cumulative Overlead (PICO). J. Spec. Oper. Med. 2016, $16,61-64$.

119. Knapik, J.; Darakjy, S.; Hauret, K. Ambulatory physical activity during United States army basic combat training. Int. J. Sports Med. 2007, 28, 106-115. [CrossRef] [PubMed]

120. Orr, R.; Moorby, G. The physical Conditioning Optimisation Project-A Physical Conditioning Continuum Review of the Army Recruit Training Course; Australian Defence Force: Canberra, Australia, 2006. 